7. Reprod. Fert. (1968) 15, 103-111

\title{
THE PERMEABILITY OF TWO- AND EIGHT-CELL MOUSE EMBRYOS TO L-MALIC ACID
}

\author{
R. G. WALES* AND J. D. BIGGERS $\dagger$ \\ King Ranch Laboratory of Reproductive Physiology, University of Pennsylvania, \\ Philadelphia, Pennsylvania, U.S.A.
}

(Received 30th November 1966)

\begin{abstract}
Summary. The level of radio-isotope in 2- and 8-cell mouse embryos was measured following a 30 -min incubation in isotopically labelled malate. Although there was very little accumulation of substrate carbon and no output of radio-active carbon dioxide by 2-cell embryos, 8-cell embryos accumulated substrate carbon during the incubation and oxidized some of the malate to carbon dioxide. A change in the concentration of malate in the medium and the addition of ouabain had little effect on the accumulation of substrate in 8-cell embryos. On the other hand, its accumulation was suppressed during incubations at $5^{\circ} \mathrm{C}$.

The evidence suggests that there is little or no uptake of malate by 2cell embryos, and that an active uptake of the compound occurs at a later stage of development.
\end{abstract}

\section{INTRODUCTION}

Biggers, Gwatkin \& Brinster (1962) showed that complete development of the mouse zygote to a blastocyst in vitro only occurred in organ cultures of Fallopian tubes. At the time these organ culture studies were done, only late 2-cell mouse embryos would develop into blastocysts completely in vitro, provided lactate was incorporated in the medium (Whitten, 1957). These results provided indirect evidence that cleavage in the mouse is dependent on the maternal environment. More recent studies have shown that development of the late 2-cell mouse embryo to the blastocyst (Brinster, 1963), and the zygote to the early 2-cell stage (Whittingham \& Biggers, 1967), can occur in a simple chemically-defined medium, only if an energy source is present. Only in the intermitotic period between the first and second cleavages is some unknown Fallopian tube factor involved. Thus, there is strong circumstantial evidence that Fallopian tube secretions supply at least an exogenous energy source to the embryo throughout cleavage.

The fact that cleaving mouse embryos require an exogenous energy source raises questions as to what energy sources can be used and how they are assimilated. Studies on the nutritional requirements of the cleaving mouse embryo

* Present address: Department of Veterinary Physiology, University of Sydney, Sydney, N.S.W. Australia.

+ Present address: Johns Hopkins School of Hygiene and Public Health, 615 N. Wolfe Street, Baltimore, Md. 21205, U.S.A. 
in vitro indicate that the energetics of early development are complex. The spectrum of compounds which can be utilized by the late 2-cell embryo is narrow, restricted to the four compounds: lactate, pyruvate, phosphoenolpyruvate and oxaloacetate (Brinster, 1963). By the 8-cell stage, however, several other compounds, such as glucose, malate, $\alpha$-ketoglutarate and citrate can be used (Whitten, 1957; Brinster \& Thomson, 1966). Two alternative mechanisms may be invoked to explain these findings. Either the energy source cannot enter the embryo until a certain stage of development is reached because of permeability barriers, or the energy source enters the early embryo, but the necessary metabolic pathways for its utilization do not develop until later. Studies of the uptake of $\mathrm{U}^{14} \mathrm{C}$-L-malate by 2- and 8-cell mouse embryos have shown that the cell membrane becomes permeable to the compound between the first and third cleavage divisions. The results are reported in this paper.

\section{MATERIALS AND METHODS}

Mouse embryos were obtained from random-bred Swiss mice superovulated by the intraperitoneal injection of $10 \mathrm{i}$.u. of serum gonadotrophin (Gestyl, Organon), followed $48 \mathrm{hr}$ later by the intraperitoneal injection of 10 i.u. of chorionic gonadotrophin (Pregnyl, Organon) (Brinster, 1963). Two-cell embryos were flushed from the Fallopian tubes of mated females 44 to $48 \mathrm{hr}$ after the second injection, while 8-cell embryos were recovered from the Fallopian tubes and upper third of the uterus approximately $24 \mathrm{hr}$ later.

The basic medium used in the study was Krebs-Ringer bicarbonate containing $1 \mathrm{mg} / \mathrm{ml}$ of crystalline bovine serum albumen, 100 i.u. $/ \mathrm{ml}$ of penicillin and $50 \mu \mathrm{g} / \mathrm{ml}$ of streptomycin. Where substrates were added to the medium, isotonicity was maintained by decreasing the sodium chloride content of the medium. For recovery and preliminary handling of the embryos, $25 \mathrm{~mm}$ sodium lactate and $0.25 \mathrm{~mm}$ sodium pyruvate were added as an energy source (Brinster, 1965). Following collection, the embryos were washed twice by transferring in a minimum volume through two changes of substrate-free medium $(3 \mathrm{ml})$. Following the second wash, the embryos were collected in a minimum of substrate-free medium, transferred to a medium containing $\mathrm{U}_{-}{ }^{14} \mathrm{C}$ L-malate $(1.7 \mathrm{~mm}$ and specific activity $4.4 \mu \mathrm{c} / \mathrm{mole})$ and incubated at $37^{\circ} \mathrm{C}$ for 30 min with air: carbon dioxide (95:5) as the gas phase. Between 150 and 250 2-cell embryos, and between ninety and 110 8-cell embryos, were incubated for each treatment. In the first tests embryological watch glasses containing $0.5 \mathrm{ml}$ of the malate medium covered with $2 \mathrm{ml}$ of light paraffin oil were used. However, in all subsequent experiments, incubations were carried out in tissue culture dishes containing $0 \cdot 1 \mathrm{ml}$ of malate medium as a droplet in $10 \mathrm{ml}$ of light paraffin oil (Brinster, 1963). This latter method was more convenient and conserved isotope. A preliminary trial showed that embryos could be incubated $30 \mathrm{~min}$ in the malate medium without loss of viability, as gauged by subsequent development into blastocysts.

A method used by Wales \& O'Shea (1966) for the measurement of intracellular constituents of spermatozoa was adopted for the rapid recovery of the embryos from the radio-active malate medium. A 2.6-ml Pichler-Spikes type centrifuge tube with a uniform bore of $2 \mathrm{~mm}$ in the capillary tip was used 
(Owens-Illinois Glass Co.). The bottom $0.5 \mathrm{~cm}$ (approximately $16 \mu \mathrm{l}$ ) was filled with $10 \% \mathrm{w} / \mathrm{v}$ sucrose solution containing $1 \%(\mathrm{v} / \mathrm{v})$ formalin, and the remaining narrow portion of the tube $(2 \mathrm{~cm})$ was filled with isotonic sucrose. Above this, approximately $1 \mathrm{ml}$ of non-radio-active malate medium $(1.7 \mathrm{~mm}$ malate) was pipetted into the wide portion of the tube. At the completion of incubation in the radio-active malate, the embryos were transferred in a minimum volume of medium to the top of the non-radio-active medium and immediately centrifuged at $500 \mathrm{~g}$ for $3 \mathrm{~min}$. The non-radio-active medium thus acted as an initial dilutor of the highly active incubation medium before centrifuging the embryos through the sucrose rinse.

After centrifugation, the supernatant medium was removed, the inner surface of the wide portion of the centrifuge tube wiped with absorbent tissue, rinsed with $1 \mathrm{ml}$ of non-radio-active diluent and again wiped dry. The sucrose column was then carefully removed to within $1 \mathrm{~cm}$ of the base of the tube. The next 0.5 $\mathrm{cm}$ of sucrose was transferred to a scintillation vial to act as a background count for the embryos. The bottom of the tube $(0.5 \mathrm{~cm})$ was then removed and

TABLE 1

RADIO-AGTIVITY IN SUCCEEDING $16 \mu$ l ALIQUOTS OF THE SUGROSE RINSE AND IN EQUIVALENT AMOUNTS OF THE SUPERNATANT AND INGUBATION MEDIUM AFTER GENTRIFUGING MOUSE EMBRYOS

\begin{tabular}{l|c|c|cccccc}
\hline \multirow{4}{*}{$\begin{array}{c}\text { Stage } \\
\text { of } \\
\text { development }\end{array}$} & \multicolumn{7}{|c}{ Radio-activity } \\
\cline { 2 - 9 } & Medium & Supernatant & \multicolumn{5}{c}{ Sucrose aliquots } \\
\cline { 3 - 9 } & & & 1 & 2 & 3 & 4 & 5 & 6 \\
\hline $\begin{array}{l}\text { 2-cell embryo } \\
\text { 8-cell embryo }\end{array}$ & 114,757 & 7,629 & 21 & 4 & 2 & 1 & 0 & 11 \\
\hline
\end{tabular}

Radio-activity is expressed as counts/min/aliquot corrected for background (26.8 counts/min). Following centrifugation and removal of the supernatant, succeeding aliquots of the sucrose rinse were withdrawn from the capillary tip of the centrifuge tube and assayed for radio-activity. The sucrose aliquots are numbered 1 to 6 from supernatant interface to base and aliquot number 6 contains the embryos.

transferred with its contents to a scintillation vial. Radio-activity was assayed by liquid scintillation techniques using toluene containing $0.5 \%$ 2,5-diphenyloxazole (PPO) and $0.03 \%$ 1-4-bis-2(4-methyl-5-phenyloxazolyl)-benzene (dimethyl POPOP) as scintillator. All samples were first dried, then incubated in $1 \mathrm{ml}$ of $1 \mathrm{~m}$ methyl dodecyl benzyl trimethyl ammonium hydroxide (Hyamine hydroxide) before the addition of $10 \mathrm{ml}$ of scintillator. Samples of low activity were counted for sufficient time to ensure accuracy. For each treatment a sample of incubation medium was assayed for radio-activity and the results used to determine the concentration of malate after the introduction of the embryos. The amount of intracellular substrate, expressed as $\mu$ atoms of substrate carbon/ embryo was calculated from the counts in the embryos, corrected for background and the specific activity of the incubation medium.

The distribution of isotope in the sucrose rinse, as shown in Table 1, indicates that the method effectively washes embryos free of radio-active medium. Little isotope was detected in the sucrose and the counts in the lower portion were 
equal to those obtained with a standard background. Thus the mean count for the sucrose overlying the embryo fraction in all experiments was 26.8 ( $\mathrm{SE}=0.34$, 32 observations) compared with a mean count of $26 \cdot 8$ ( $\mathrm{SE}=0 \cdot 15,8$ observations) for a standard background.

To measure ${ }^{14} \mathrm{C}$-carbon dioxide production, embryos were incubated in $0 \cdot 1$ $\mathrm{ml}$ of radio-active malate medium covered with a thin layer of light paraffin oil. Following incubation for $3 \mathrm{hr}$ in sealed vials that had been flushed with air: carbon dioxide (95:5), metabolism was terminated by the injection of $0.1 \mathrm{ml}$ of $0.2 \mathrm{~N} \mathrm{H}_{2} \mathrm{SO}_{4}$ and the evolved carbon dioxide absorbed with $0.2 \mathrm{ml}$ of $2 \mathrm{~N}$ $\mathrm{NaOH}$. The absorbed carbon dioxide was precipitated as barium carbonate, collected on a filter disc, washed and quantitatively transferred to a scintillation vial in $2 \mathrm{ml}$ of ethanol. The precipitate was dispersed in $10 \mathrm{ml}$ of scintillator with the aid of an ultrasonic disintegrator and suspended with a thixotropic gel powder (Carb-O-Sil, Packard Instrument Company). As a consistent amount of radio-active carbon dioxide was collected from samples of the malate medium treated in this way, blanks containing no embryos were used as controls.

\section{RESULTS}

The level of intracellular substrate carbon in normal 2- and 8-cell mouse embryos incubated in $\mathrm{U}^{14} \mathrm{C}$-malate is shown in Table 2 . There was little accumu-

TABLE 2

THE AGGUMULATION OF SUBSTRATE CARBON BY MOUSE EMBRYOS DURING A 30-MIN INCUBATION IN A DILUENT CONTAINING L-MALATE

\begin{tabular}{c|c|c}
\hline $\begin{array}{c}\text { Stage } \\
\text { of } \\
\text { development }\end{array}$ & $\begin{array}{c}\text { No. } \\
\text { of } \\
\text { observations }\end{array}$ & $\begin{array}{c}\text { Substrate carbon } \\
\text { accumulated } \\
\left(\text { ggatoms } \times 10^{-8} / \text { embryo }\right)\end{array}$ \\
\hline 2-cell & 4 & $7 \cdot 3 \pm 2 \cdot 9$ \\
8-cell & 7 & $56 \cdot 2 \pm 5 \cdot 0$ \\
\hline
\end{tabular}

Mean values \pm standard errors of the means are given.

lation of substrate in 2-cell embryos following a 30-min incubation and the values represent counts only $57 \%$ higher than the corresponding background. On the other hand, significant amounts of substrate accumulated in 8-cell embryos and values were approximately eight times those found at the earlier stage in development.

The production of carbon dioxide from malate by 2- and 8-cell embryos was also measured. Two samples of 8-cell embryos produced $350 \times 10^{-8} \mu$ mole and $420 \times 10^{-8} \mu$ mole of carbon dioxide per embryo, respectively, during a 3-hr incubation. However, no carbon dioxide was produced by either of two samples of 2-cell embryos under similar conditions.

To examine the effect of removal of the zona pellucida on the accumulation of substrate carbon, 2- and 8-cell mouse embryos were collected. Before washing and incubation, half of each sample was incubated in a $0.25 \%$ solution of Pronase in phosphate buffered saline, containing $1 \%$ polyvinylpyrrolidone (pH 7.6) until the zona pelludica was digested (Mintz, 1962; Gwatkin, 1963). 
The uptake of malate by these cells was then compared with that of the remaining untreated embryos (Table 3 ). Although the results are somewhat variable it seems that Pronase treatment had no effect on 2-cell embryos. In contrast, the accumulation of substrate by 8-cell embryos was significantly depressed by this treatment $\left(t_{(2)}=7.7,0.01<P<0.05\right)$.

TABLE 3

\begin{tabular}{|c|c|c|c|}
\hline \multirow{2}{*}{$\begin{array}{c}\text { Stage } \\
\text { of } \\
\text { development }\end{array}$} & \multirow{2}{*}{ Replicates } & \multicolumn{2}{|c|}{$\begin{array}{l}\text { Substrate carbon accumulated } \\
\left(\mu \text { gatoms } \times 10^{-8} / \text { embryo }\right)\end{array}$} \\
\hline & & $\begin{array}{c}\text { Untreated } \\
\text { control }\end{array}$ & $\begin{array}{l}\text { Pronase } \\
\text { treated }\end{array}$ \\
\hline 2-cell & $\begin{array}{l}1 \\
2 \\
3\end{array}$ & $\begin{array}{r}3 \cdot 5 \\
15 \cdot 4 \\
5 \cdot 2\end{array}$ & $\begin{array}{l}4 \cdot 1 \\
3 \cdot 6 \\
4 \cdot 8\end{array}$ \\
\hline 8-cell & $\begin{array}{l}1 \\
2 \\
3\end{array}$ & $\begin{array}{l}69 \cdot 5 \\
53 \cdot 3 \\
77 \cdot 6\end{array}$ & $\begin{array}{l}40.4 \\
21.8 \\
34.8\end{array}$ \\
\hline
\end{tabular}

The effect of varying the concentration of malate on the accumulation of substrate carbon by 8-cell embryos is shown in Table 4 . A decrease in the concentration of malate during incubation from $1.17 \mu \mathrm{mole} / \mathrm{ml}$ to $0.117 \mu \mathrm{mole} /$ $\mathrm{ml}$ caused a small $(25 \%)$ decrease in the accumulation of substrate carbon by the embryos.

The uptake of malate by 8-cell embryos at low temperature was examined in the next experiment. After collection, the embryos were divided into three equal groups in separate embryological watch glasses containing $1 \mathrm{ml}$ of medium

TABLE 4

THE EFFECT OF A GHANGE IN MALATE CONGENTRATION ON THE AGCUMULATION OF SUBSTRATE CARBON BY 8-CELL MOUSE

EMBRYOS

\begin{tabular}{c|c|c}
\hline \multirow{2}{*}{$\begin{array}{c}\text { Malate concentration } \\
(\mu \text { mole/ml })\end{array}$} & \multicolumn{2}{|c}{$\begin{array}{c}\text { Substrate carbon accumulated } \\
\left(\mu g a t o m s \times 10^{-8} / \text { embryo }\right)\end{array}$} \\
\cline { 2 - 3 } & Rep 1 & Rep 2 \\
\hline $1 \cdot 17$ & 35.9 & 40.8 \\
0.117 & 24.0 & 32.0 \\
\hline
\end{tabular}

covered with $2 \mathrm{ml}$ of light paraffin oil. Two groups were slowly cooled to $5^{\circ} \mathrm{C}$ over $30 \mathrm{~min}$ by standing in a shallow dish of water in a refrigerated room while the third was maintained at $37^{\circ} \mathrm{C}$. A preliminary trial indicated that embryos so cooled showed no loss of viability as gauged by their subsequent development into blastocysts. One of the cooled groups was re-warmed for washing and incubation with the control, uncooled group. The other cooled group was washed 
twice, incubated $30 \mathrm{~min}$ in the presence of radio-active malate and separated from the incubation medium, all at $5^{\circ} \mathrm{C}$. The results for two replicates (Table 5) showed that the accumulation of substrate carbon was greatly depressed by incubation in malate at $5^{\circ} \mathrm{C}$ and was similar to that found in 2-cell embryos. On the other hand, embryos incubated in malate at $37^{\circ} \mathrm{C}$, after cooling, accumulated substrate carbon as readily as the controls.

TABLE 5

EFFECT OF INGUBATION IN L-MALATE AT $5^{\circ} \mathrm{C}$ ON THE AMOUNT OF SUBSTRATE CARBON IN 8-CELL MOUSE EMBRYOS

\begin{tabular}{l|c|c|c}
\hline Pretreatment & $\begin{array}{c}\text { Temperature } \\
\text { of } \\
\text { incubation }\end{array}$ & \multicolumn{2}{|c}{$\begin{array}{c}\text { Substrate carbon accumulated } \\
\left(\mu g a t o m s \times 10^{-8} / \text { embryo }\right)\end{array}$} \\
\cline { 2 - 3 } & Rep 1 & Rep 2 \\
\hline Nil (control) & $37^{\circ} \mathrm{C}$ & $58 \cdot 1$ & $47 \cdot 7$ \\
Cooled to $5^{\circ} \mathrm{C}$ & $37^{\circ} \mathrm{C}$ & 54.9 & $44 \cdot 4$ \\
Cooled to $5^{\circ} \mathrm{C}$ & $5^{\circ} \mathrm{C}$ & 14.5 & 8.9 \\
\hline
\end{tabular}

An attempt was made to block the uptake of malate by 8-cell mouse embryos with ouabain, an inhibitor of sodium-potassium dependent adenosine triphosphatase important in active transport of some substances across cell membranes (see Repke (1964) for a review).

The accumulation of substrate carbon by 8-cell mouse embryos in the presence of varying concentrations of ouabain was compared with that of control incubations containing no ouabain. The results (Table 6) indicate that

TABLE 6

$$
\begin{aligned}
& \text { EFFECT OF OUABAIN ON THE AMOUNT OF } \\
& \text { SUBSTRATE GARBON IN 8-CELL MOUSE } \\
& \text { EMBRYOS INCUBATED IN L-MALATE }
\end{aligned}
$$

\begin{tabular}{|c|c|c|c|}
\hline \multirow{2}{*}{$\begin{array}{l}\text { Ouabain } \\
\text { concentration } \\
\text { (M) }\end{array}$} & \multicolumn{3}{|c|}{$\begin{array}{c}\text { Substrate carbon accumulated } \\
\left(\mu \text { gatoms } \times 10^{-8} \text { (embryo }\right)\end{array}$} \\
\hline & Rep 1 & $\operatorname{Rep} 2$ & $\operatorname{Rep} 3$ \\
\hline $\begin{array}{c}0 \\
10^{-7} \\
10^{-6} \\
10^{-5}\end{array}$ & $\begin{array}{l}44 \\
28 \\
56 \\
36\end{array}$ & $\begin{array}{l}44 \\
37 \\
37 \\
36\end{array}$ & $\begin{array}{l}52 \\
50 \\
-\end{array}$ \\
\hline
\end{tabular}

there is no effect of ouabain on the amount of intracellular substrate carbon during the $30-\mathrm{min}$ incubation period.

\section{DISCUSSION}

\section{UTILIZATION OF L-MALATE}

Brinster (1966) has shown that NAD-dependent malic dehydrogenase is present in both 2- and 8-cell embryos and that oxaloacetate is able to support development at both stages (Brinster, 1965; Brinster \& Thomson, 1966). Thus, it would 
be expected that, if malate could penetrate the cell wall of the 2-cell embryo, it would be utilized provided there was no inhibition of the dehydrogenase in vivo. However, it has been shown that malate will not support development at this stage (Brinster, 1965) and, in the present studies, oxidative utilization of malate by 2-cell embryos could not be demonstrated. In addition, the almost complete absence of substrate carbon in embryos at this stage indicates that there is no uptake of the substrate rather than an enzymic inhibition.

By comparison, there were consistently higher concentrations of isotopically labelled carbon in 8-cell embryos incubated in the presence of $\mathrm{U}^{14} \mathrm{C}$-malate, and a significant production of labelled carbon dioxide during incubation in its presence. These findings, plus the fact that a proportion of these embryos continue to develop with malate as sole substrate (Brinster \& Thompson, 1966), indicate that this compound penetrates the 8-cell embryo and is utilized by oxidative pathways.

If $138,000 \mu^{3}$ is assumed to be the mean volume of the 8-cell mouse embryo (from data of Lewis \& Wright, 1935), the values presented in Table 4 would give concentrations of intracellular substrate carbon of 2.78 and $2.02 \mu$ gatoms $/ \mathrm{ml}$ when the extracellular values were $4.68 \mu$ gatoms $/ \mathrm{ml}$ and $0.47 \mu \mathrm{gatoms} / \mathrm{ml} \mathrm{re}-$ spectively. If the majority of substrate carbon in the cell was malate, the latter figure could indicate that uptake occurs against a concentration gradient. However, as very low levels of labelled substrate carbon were found even in 8-cell embryos, it was impossible to identify positively the intracellular constituent accumulating.

In the renal tubule it has been shown that three polycarboxylic acids of the tricarboxylic acid cycle, namely malate, $\alpha$-ketoglutarate and citrate, are reabsorbed by active transport probably via a common mechanism (Vishwakarma \& Miller, 1963). These three acids will not support the development of 2-cell mouse embryos but will support development of 8-cell stages (Brinster \& Thomson, 1966). The present studies indicate that malate enters the 8-cell embryo by an active process. A change of substrate concentration in the incubation medium had a minor effect on the intracellular accumulation of substrate carbon whereas incubation at $5^{\circ} \mathrm{C}$ inhibited the accumulation. However, ouabain had no effect and it is unlikely therefore that the uptake of malate is linked to the sodium-potassium dependent adenosine triphosphatase as has been found for some non-electrolytes in other tissues (see Csaky, 1965).

The lack of accumulation of substrate carbon by 2-cell embryos during incubations in malate is not due to the impermeability of the zona pellucida at this stage. It has been shown that in the rabbit, rat and hamster the zona is permeable to substances with a molecular weight of at least 1200 (Austin \& Lovelock, 1958) and, in the present experiments, removal of the zona by Pronase did not increase the uptake by 2-cell embryos. The effect of Pronase on the uptake of malate by 8-cell embryos is probably due to an effect of the non-specific proteolytic enzyme on cell constituents decreasing active uptake rather than to a direct effect of the removal of the zona pellucida freeing isotopic malate trapped in the perivitelline space. The tendency of some blastomeres to separate during treatment with this enzyme indicates that even with due precautions, there is some effect of the enzyme on the cell surface. 
BIOCHEMICAL DIFFERENTIATION IN THE GLEAVING MOUSE EMBRYO

The work on the nutritional requirements of mouse embryos referred to in the introduction to this paper shows that the cleaving embryo is dependent on an exogenous supply of energy. Moreover, an increasing number of compounds can be used as development proceeds. The work described in the present paper has allowed us to identify more specifically one mechanism, namely a change in permeability, which may be involved in regulating development. Since active transport seems to be concerned in the uptake of malate by the mouse embryo the activation of a membrane-linked enzyme may be involved. The work of Fridhandler (1961) on the rabbit showed that initially the pentose phosphate pathway is the main route of energy metabolism, which is later replaced by the Emden-Myerhoff pathway. Thus, the joint evidence shows that more than one type of change in biochemical function may occur during cleavage in mammalian embryos. Cleavage, therefore, is not merely six to seven mitotic divisions in which a relatively undistinguished cytoplasm is shared out among the nuclei until some 64 to 128 cells are produced.

Although the ovum of a marine organism like Arbacia is very similar in size to the mouse ovum, there are at least two crucial differences in the mechanisms involved in cleavage of the two species. First, Arbacia readily cleave in artificial sea water which is devoid of an exogenous energy source (Shapiro, 1941), whereas a mouse requires an exogenous source of energy. Secondly, strong evidence exists that cleavage of the Arbacia egg until gastrulation is regulated by messenger RNA, which is performed in the oocyte (Gross \& Cousineau, 1964), whereas, in the mouse, studies on the effect of actinomycin D on cleavage suggest that some synthesis of messenger RNA is necessary even at the 2-cell stage (Thomson \& Biggers, 1966). Conclusive evidence of gene action during cleavage in the mouse is provided by two mutants $\left(\mathrm{t}^{1}\right.$ and $\left.\mathrm{t}^{12}\right)$ which are lethal during cleavage in the homozygous state (Gluecksohn-Schoenheimer, 1938; Smith, 1956). In addition, the work of Fridhandler (1961) in the rabbit together with the demonstration that an active transport mechanism for the uptake of malate develops after the second cleavage may indicate that the differential reading of the genome begins early in cleavage.

\section{ACKNOWLEDGMENTS}

This work was aided by grants from the Population Council and the National Science Foundation (Grant No. GB 4465). One of the authors (R.G.W.) is also indebted to the Population Council for the provision of a fellowship while on sabbatical leave from the Department of Veterinary Physiology, University of Sydney, Australia.

\section{REFERENCES}

Austin, C. R. \& Lovelock, J. E. (1958) Permeability of rabbit, rat and hamster egg membranes. Expl Cell Res. 15, 260.

Biggers, J. D., Gwatkin, R. B. L. \& Brinster, R. L. (1962) Development of mouse embryos in organ cultures of fallopian tubes on a chemically defined medium. Nature, Lond. 194, 747.

BRINSTER, R. L. (1963) A method for in vitro cultivation of mouse ova from two-cell to blastocyst. Expl Cell Res. 32, 205. 
BRINSTER, R. L. (1965) Studies on the development of mouse embryos in vitro. IV. Interaction of energy sources. F. Reprod. Fert. 10, 227.

BRINSTER, R. L. (1966) Malic dehydrogenase activity in the pre-implantation mouse embryo. Expl Cell Res. 43, 131.

Brinster, R. L. \& Thomson, J. L. (1966) Development of eight-cell mouse embryos in vitro. Expl Cell Res. 42, 308.

Csaky, T. Z. (1965) Transport through biological membranes. A. Rev. Physiol. 27, 415.

Fridhandere, L. (1961) Pathways of glucose metabolism in fertilized rabbit ova at various preimplantation stages. Expl Cell Res. 22, 303.

Gluecksohn-Schoenheimer, S. (1938) Time of death of lethal homozygotes in the T (Brachyury) series in the mouse. Proc. Soc. exp. Biol. Med. 39, 267.

Gross, P. R. \& CousineAU, G. H. (1964) Macromolecule synthesis and the influence of actinomycin on early development. Expl Cell Res. 33, 368.

Gwatkin, R. B. L. (1963) Effect of viruses on early mammalian development. I. Action of Mengo encephalitis virus on mouse ova cultivated in vitro. Proc. natn. Acad. Sci. U.S.A. 50, 576.

LEWIS, W. H. \& WRIGHT, E. S. (1935) On the development of the mouse. Contr. Embryol. 25, 113.

Mintz, B. (1962) Experimental study of the developing mammalian egg: removal of the zona pellucida. Science, N.Y. 138, 594.

RepKe, K. (1964) Uber den biochemischen Wirkungsmodus von Digitalis. Klin. Wschr. 42, 157.

Shapiro, H. (1941) Centrifugal elongation of cells, and some conditions governing the return to sphericity, and cleavage time. F. cell. comp. Physiol. 18,61.

Sмrтн, L. J. (1956) A morphological and histochemical investigation of a pre-implantation lethal $\left(\mathrm{t}^{12}\right)$ in the house mouse. F. exp. Zool. 132, 51 .

Thomson, J. L. \& Biggers, J. D. (1966) Effect of inhibitors of protein synthesis on the development of preimplantation mouse embryos. Expl Cell Res. 41, 411.

Vishwakarma, P. \& Miller, T. (1963) Renal tubular transport of citrate: relations with calcium. Am. 7. Physiol. 205, 281.

Wales, R. G. \& O'SheA, T. (1966) The oxidative utilization of fructose and acetate by washed ram spermatozoa in the presence or absence of potassium and magnesium. Aust. F. biol. Sci. 19, 167.

Whrrten, W. K. (1957) Culture of tubal ova. Nature, Lond. 179, 1081.

Whittingham, D. G. \& Biggers, J. D. (1967) Fallopian tube and early cleavage in the mouse. Nature, Lond. 213, 942. 